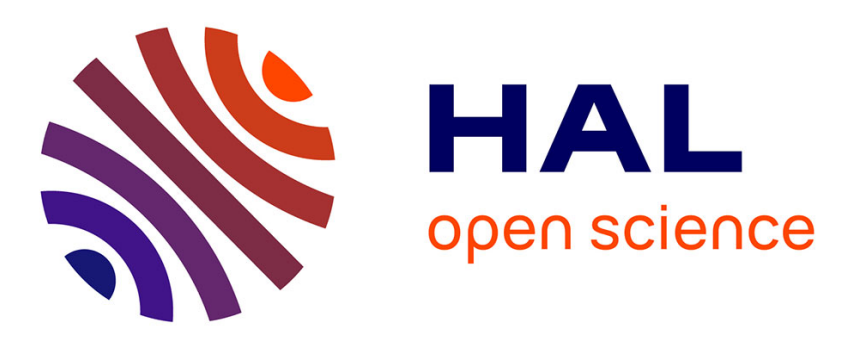

\title{
Palaeoecological study of Pyrenean lowland fir forests: Exploring midelate Holocene history of Abies alba in Montbrun (Ariiège, France)
}

Raquel Cunill, Jean-Paul Métailié, Didier Galop, Sébastien Poublanc, Nicolas de Munnik

\section{To cite this version:}

Raquel Cunill, Jean-Paul Métailié, Didier Galop, Sébastien Poublanc, Nicolas de Munnik. Palaeoecological study of Pyrenean lowland fir forests: Exploring midelate Holocene history of Abies alba in Montbrun (Ariiège, France). Quaternary International, 2015, 366, pp.37-50. 10.1016/j.quaint.2014.12.050 . hal-01174876

\section{HAL Id: hal-01174876 https://hal.science/hal-01174876}

Submitted on 10 Jul 2015

HAL is a multi-disciplinary open access archive for the deposit and dissemination of scientific research documents, whether they are published or not. The documents may come from teaching and research institutions in France or abroad, or from public or private research centers.
L'archive ouverte pluridisciplinaire HAL, est destinée au dépôt et à la diffusion de documents scientifiques de niveau recherche, publiés ou non, émanant des établissements d'enseignement et de recherche français ou étrangers, des laboratoires publics ou privés. 


\title{
Palaeoecological study of Pyrenean lowland fir forests: Exploring mid-late Holocene history of Abies alba in Montbrun (Ariège, France)
}

\author{
Raquel Cunill a, c, ", Jean-Paul Métailié a , Didier Galop a , Sébastien Poublanc ${ }^{\mathrm{b}}$, \\ Nicolas de Munnik ${ }^{\text {a }}$ \\ a Laboratoire GEODE, UMR 5602 CNRS, Université Toulouse II-Jean-Jaurès, 5 allées Antonio Machado, 31058 Toulouse, France \\ ${ }^{\mathrm{b}}$ FRA.M.ESPA, UMR 5136 CNRS, Université Toulouse II-Jean-Jaurès, 5 allées Antonio Machado, 31058 Toulouse, France \\ c GRAMP, Departament de Geografia, Universitat Autònoma de Barcelona, 08193, Bellaterra, Cerdanyola del Vallès, Spain
}

\section{A R T I C L E I N F O}

Article history:

Available online $\mathrm{xxx}$

\section{Keywords:}

Soil charcoal

Pedoanthracology

Abies alba

Pyrenees

Forest history

Holocene

\begin{abstract}
A B S T R A C T
Fir (Abies alba Mill.) occupies an important place in the Pyrenean context, where the species finds its optimal conditions in this mountain zone ( $800-1800 \mathrm{~m}$ a.s.l.). In the Pyrenees, the fir woods of Volvestre (Ariège, France) are of particular interest because of two peculiarities of its location: its northern latitude with respect to the usual location of fir in the Pyrenean axis, and its lower altitude (330-440 $\mathrm{m}$ a.s.l.). This has given rise to various theories, some considering the silver fir forests as a glacial relic and others pointing to anthropogenic interference and possible plantings during the Middle Ages. Pedoanthracological and palynological studies have been performed to establish the origin and history of this ancient forest, and both approaches show an ancient anthropized landscape with a continuous presence of Abies alba throughout the mid- and late-Holocene. The fir woodlands of Volvestre are testimonies to the ancient and significant presence of fir on the northeast slope of the Pyrenees and the current suitability of this species for lowland areas. Pedoanthracological sampling inside the forest has shown differences in vegetation dynamics at different valley points (north slope, south slope, and valley bottom).
\end{abstract}

() 2014 Elsevier Ltd and INQUA. All rights reserved.

\section{Introduction}

Abies Alba Mill. currently extends throughout the principal mountain regions of Central and Southern Europe. In the Pyrenees, the fir tree appears to find optimal conditions in the mountain and subalpine range, between $800 \mathrm{~m}$ and $1800 \mathrm{~m}$ above sea level, on north-facing slopes.

Previous research has shown that the distribution of Abies alba in Europe is more limited at present than during the middle Holocene, when it was dominant in the mountain areas and even in the lower lands (Tinner et al., 1999; Carcaillet and Muller, 2005; Tinner and Lotter, 2006; Wick and Möll, 2006; Tinner et al., 2013). In the Pyrenees, palynological studies have confirmed this pattern (Jalut et al., 1988; Pèlachs et al., 2009; Galop et al., 2013). In addition, various models of the presence of Pyrenean fir were

\footnotetext{
* Corresponding author. Laboratoire GEODE, UMR 5602 CNRS, Université Toulouse II-Jean-Jaurès, 5 allées Antonio Machado, 31058 Toulouse, France. GRAMP, Departament de Geografia, Universitat Autònoma de Barcelona, 08193 Bellatera, Cerdanyola del Vallès, Spain.

E-mail address: cunillraquel@gmail.com (R. Cunill).
}

recently carried out from the topoclimatic point of view based on current climatic conditions of fir populations (Alba-Sánchez et al., 2009, 2010; Serra-Diaz et al., 2012). These models highlighted the more limited current extension of the fir tree in the Pyrenees than was expected (Fig. 1).

Topoclimatic spatial distribution models have been developed for the Pyrenees, based on current climate conditions (AlbaSánchez et al., 2009, 2010; Serra-Diaz et al., 2012). Compared to the potential distribution in the models, the current extent of Abies in the Pyrenees is more limited than expected, occupying $30 \%$ of the optimal potential area and a wider altitudinal interval (AlbaSánchez et al., 2009). A similar trend was found at a more general level for southeastern Europe (Tinner et al., 2013) (see Fig. 2).

Recent phylogenetic studies show that the Pyrenean populations of Abies have strong genetic originality, pointing to their long-term isolation from the other European populations during the Quaternary glacial periods (Konnert and Bergmann, 1995; Fady et al., 1999; Terhürne-Berson et al., 2004; Liepelt et al., 2009). However, contact with the alpine settlements or with populations in the southeast of France (Pèlachs et al., 2010) cannot be excluded. Given the current data, it is even more difficult to say which areas 


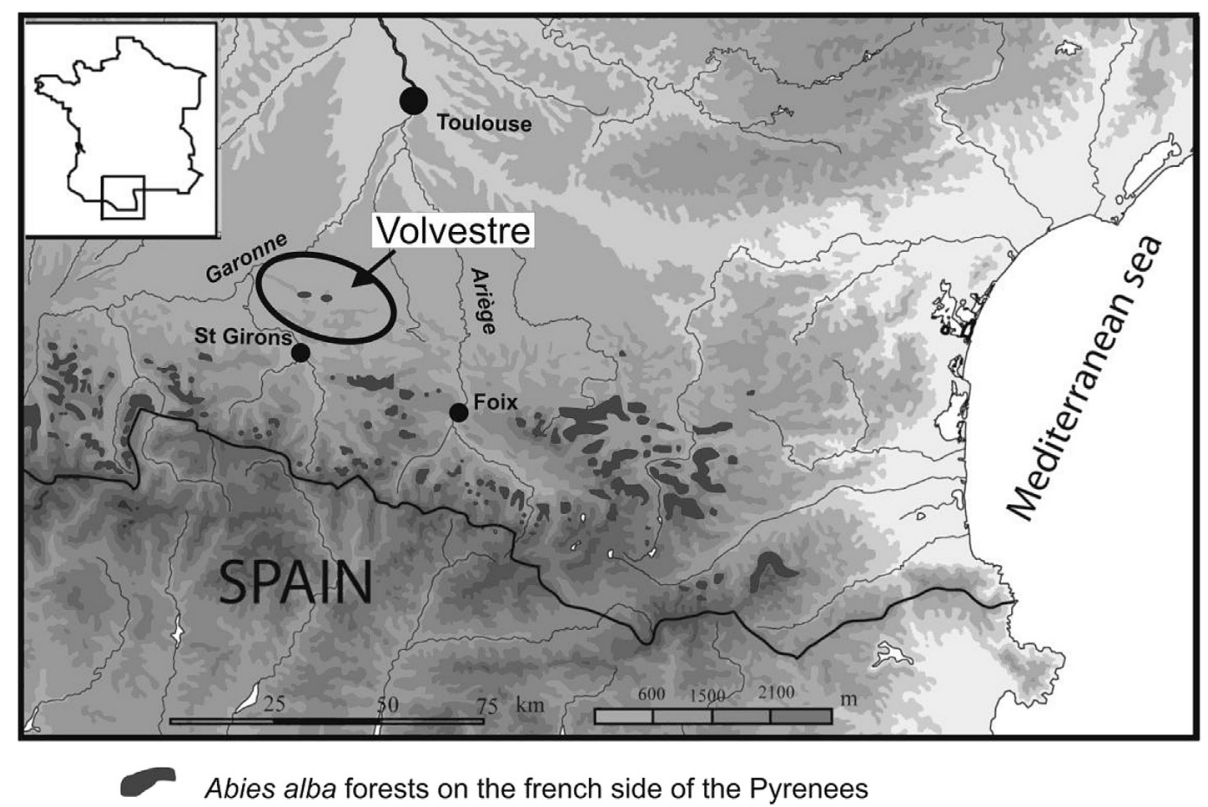

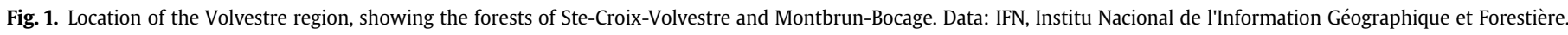

would have been glacial refuges and which were the pathways of postglacial migration. However, the data indicate that fir colonized both sides of the Pyrenean massif from east to west (Jalut et al., 1996; Esteban et al., 2003; Pèlachs, 2005). On the south Pyrenean slope, the first early Holocene presence was in interior valleys of the southeast Pyrenean foothills (Pérez-Obiols, 1988; Burjachs and Julià, 1994; Pérez-Obiols and Julià, 1994; Burjachs, 1994). On the north side, the first Abies palynological data are found in Nohèdes, at $60 \mathrm{~km}$ from the Mediterranean coast, towards 9300 cal BP (Reille and Loewe, 1993). However, the expansion towards the northwest of the Pyrenees occurs after the climatically favourable event (of the $8200 \mathrm{cal}$ BP type) that occurred between 7300-6600 cal BP and 3550-3200 cal BP (Galop and Jalut, 1994; Galop, 1998).
The current distribution of the fir tree cannot be explained solely by environmental factors (climate, soil, topography); therefore, it is necessary to take into account the anthropic factors. Over the long term, the palynological data show anthropic determinism of the dynamics of fir woodlands on both sides of the Pyrenees during the second half of the Holocene (Galop and Jalut, 1994; Galop, 1998; Pèlachs, 2005; Ejarque et al., 2010). At the scale of the last two millennia, the history and spatial distribution of fir woodlands has been characterized in many areas, in particular in the eastern half of the range. The impact of iron metallurgy and related charcoal production was a determining factor for the evolution of the forests in most valleys of Ariège and Catalonia, and provoked the near disappearance of the fir

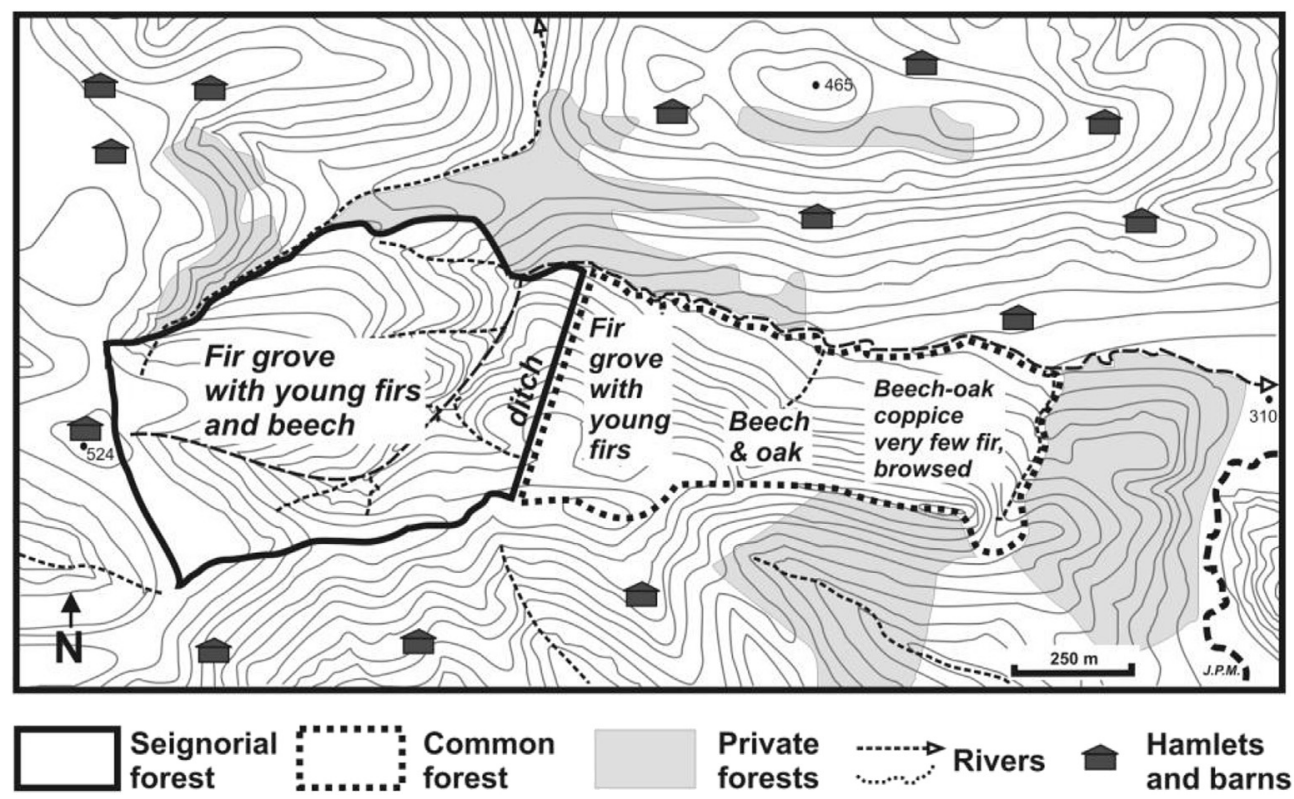

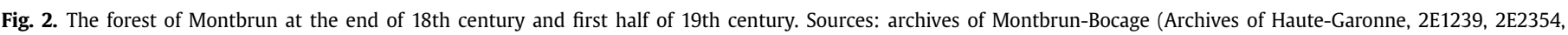
2E1961); topographic map of 1849 (IGNF_SCAN_EM_40K_1-0__2009-07-02_SCAN_4EM242SO_40K_1849). 
tree, replaced by beech and oak coppices or pastures. These activities and their environmental impacts were determined by palynological or anthracological kiln site analysis on both sides of the Pyrenees (Bonhôte and Fruhauf, 1990; Galop and Jalut, 1994; Bonhôte, 1998; Bonhôte et al., 2002; Pèlachs et al., 2009). It could also highlight an early role such as during the Middle Ages of the management of fir groves by communities or landlords, in order to preserve a disappearing resource (Bonhôte, 1998; Dubois and Métailié, 2001; Métailié, 2006). In the regions where rafting was possible (high valley of the Aude; the Garonne valley), the fir forests were preserved because of their interest for the navy and for lumber, and the possibility of trading along the Garonne river (Fruhauf, 1980; Métailié et al., 1989). However, in spite of this very strong human pressure since the Neolithic era, one cannot exclude the influence of climatic oscillations to explain the distribution of the species. There is a frequent superposition of climate and anthropic changes that makes it difficult to determine where one influence starts and another ends (Tinner et al., 1999).

Within this general framework, the fir woodlands of the Volvestre area constitute an anomaly and a very good example of the multiple knowledge gaps about the fir tree that exist in the Pyrenean context (Blanco et al., 1997). These silver fir forests are distant from the chain in the Piedmont hills, and disjunct from the current mountain fir forests (Fig. 1). In addition, the altitude $(350-450 \mathrm{~m})$ that characterizes these fir forests is the lowest elevation in the southern part of France. This particular location in the Pyrenean range gives rise to various hypotheses. One generally regards these woodlands as a relic inherited from a glacial refuge or from postglacial-way migrations. Others interpret their presence as the result of planting trees at the initiative of an abbey built in Sainte-Croix-Volvestre ("Holy Cross") during the 12th century, which received the forest in donation and remained the landlord until the French Revolution of 1789 (Gonin et al., 2012; Cunill et al., 2014). Until now, no research had been undertaken to test these hypotheses. Due to the importance of the fir tree in Pyrenean forestry and the questions about its local future in the context of global climate change, an interdisciplinary research program was set up to study the genetics and the dynamics of the Pyrenean fir forests, particularly in the Volvestre region (Gonin et al., 2012). They provide an exemplary site for the application of an interdisciplinary methodology to explore environmental history: What information can these forests give us on the postglacial migrations of the species? Is their origin natural or anthropic? Which is the ancient and current distribution range of fir in the Pyrenees? What is the historical relationship between these forests and the environmental history of the area? Can we reconstruct and spatialize the history of the land management in the area with pedoanthracology?

To answer these questions, a multiproxy approach was chosen for the present study, drawing from pedoanthracology, palynology, historical sources, and phytogeographical and geomorphological study of the area. Each of these methodologies contributes to a more thorough understanding of the environmental geohistory, providing different and complementary insights. In this paper, we present the pedoanthracological findings, supported by preliminary palynological results.

Soil charcoal analysis allows us to determine with great spatial precision the vegetation dynamics in the various geofacies identified within the same forest. It permits the precise localization of the dynamics assessed with palynology at a wider scale. On the other hand, palynology provides a long chronology and an overall context of the vegetation dynamics not limited to woody plants, highlighting the impact of agro-pastoral colonization and fires (Robin et al., 2011, Cunill et al., 2013). The results of both methodologies can also be connected to the historical data on forest management practices.

\section{Study area}

Volvestre is a relatively marginal area in the Pyrenean range. It was the object of restricted research on vegetation (Gonin, 1993; Savoie, 1995) in comparison with the upper valleys, which attracted the naturalists since the 18th century. Some ancient studies on geomorphology are available (Goron, 1942; Taillefer, 1951) but the historians, in particular, never worked on the problem of the forest. No researches on paleoecology or forest history were undertaken before the research project implemented in 2009 (Gonin et al., 2012), which made it possible to look further into ecological data gathered on the area and to develop a multi-proxy study on the long history of the environment.

\subsection{Description of the region}

The hills of the Volvestre area are located in the piedmont on the northern slope of the Pyrenees (Fig. 1). This geological region is composed of limestone, marlstone, and sandstone of Jurassic, Cretaceous, and Eocene origin, with folds oriented east to west, between 300 and $600 \mathrm{~m}$ a.s.l., constituting the "Small Pyrenees" (BRGM, 1979). The area is also characterized by the presence of PlioQuaternary alluvia surmounting the hills, which form terraces that dominate the valleys and left many colluvial deposits on the slopes. Thus, there exists an alternation of calcic brown soils on limestone, of compact argillaceous soils on the marls, of deep sandyargillaceous soils on the weathered sandstones, and of acidic and stony soils on the Plio-Quaternary alluvia and colluvial deposits (Goron, 1942; Taillefer, 1951; Hubschman, 1975; BRGM, 1979).

The climate is moderate oceanic with an average annual temperature of $11.9{ }^{\circ} \mathrm{C}$ and average annual precipitation of $900 \mathrm{~mm}$. In summer, average temperature is $21^{\circ} \mathrm{C}$ and there is no summer drought (Gonin et al., 2012). The vegetation is mainly dominated by broadleaved forest trees, such as oaks (Quercus petraea (Matt.) Liebl., Quercus pubescens Willd., Quercus robur L.) along with beech (Fagus sylvatica L.), chestnut (Castanea sativa Miller), and a set of very diversified trees and shrubs (Fraxinus excelsior L., Tilia cordata Mill., Betula pubescens Erhr., Prunus avium L., Carpinus betulus L., Salix caprea L., Acer campestre L., Alnus glutinosa L., Ligustrum vulgare L., Crataegus monogyna Jacq., Juniperus communis L., Ilex aquifolium L., Pyrus malus L. Ruscus aculeatus L., Rosa sp., Calluna vulgaris L., Vaccinium myrtillus L., Pteridium aquilinum (L) Kuhn). On the sunny slopes of the calcareous hills, the holm oak (Quercus ilex L.) can be found, accompanied by Mediterranean shrubs (Lavandula angustifolia Mill., Thymus vulgaris L., Genista scorpius L., etc) (Gonin, 1993; Savoie, 1995). High fir forests are found mainly in two areas, SainteCroix-Volvestre (200 ha, ancient abbey forest, 120 ha of fir groves) and Montbrun-Bocage (140 ha, ancient seignorial and common forest, 17 ha of fir groves). However, in the Volvestre area the fir is dispersed over nearly 1500 ha (National Forest Inventory data). Historically, since at least the Middle Ages, all the forests of the Volvestre area were managed as coppice, sometimes as coppice with standards. The fir woodlands of Sainte-Croix and Montbrun were managed to meet the timber demand for buildings and navy ships. The rate of afforestation of the Volvestre area was always high and reached 30\%-40\% in the 19th century, at the time of the strongest decline in forest cover. This rate currently ranges from $40 \%$ to $80 \%$, according to the communes (townships), because of the natural increase at the expense of fallowed fields and pastures, but also due to the planting of coniferous trees in the second half of the 20th century (Pinus sylvestris, L.; Pinus nigra, R. Legay; Pseudotsuga 
menziessi, (Mirb.) Franco; and Picea abies, (L.) H. Karst) (National Forest Inventory data).

\subsection{Forest of Montbrun-Bocage}

The forest of Montbrun-Bocage is located in a small east-west valley excavated into the anticline of the Plantaurel and Petites Pyrénées that skirts the northern slope of the central Pyrenees. The rocks are mainly sandstone and marlstone of Maastrichtian (upper Cretaceous) (BRGM, 1979), covered with thick weathering and colluvium that were notched in the upper part of the watershed by deep ravines. The altitude ranges from $310 \mathrm{~m}$ a.s.l. downstream to the east to $524 \mathrm{~m}$ a.s.l. upstream in the west. The ridges are covered by the remains of a Plio-Quaternary alluvial cone (Taillefer, 1951), where pebbles abound. The bottom of the main thalweg is filled by alluvial sedimentation that can reach 3-4 m deep, with pebbles from the upper alluvial terraces.

The forest vegetation is mainly composed by oak, beech, chestnut, and fir. The fir woodlands have been managed since at least the 18th century to obtain groves and timber production for construction projects or masts for navy ships, while beech, oaks, and chestnut were managed in coppice, or coppice with standards, for local uses and firewood. The forest is mainly located on the north- and east-facing slopes; the sunny slope was mainly pastures and agricultural terraces until the 1950s. However, small parcels of woodland were always maintained on private lands.

The earliest precise historical sources (e.g., forest survey of 1746, archives of the revolutionary period, topographic map of 1849) attest that the limits of the forest, which is surrounded by ancient hamlets and barns, have changed little since the 17th century. At the end of the 18th century, the "forest of Montbrun-Bocage" included a communal forest of 66 ha (beech-fir groves and coppices of oak, beech, and chestnut) in the eastern part and a seignorial forest of 77 ha (beech-fir groves) in the west (see Fig. 2). The seignorial forest was sold off piecemeal during the first half of the 19th century, while 40 ha of the communal forest was sold in 1861, the commune keeping only the broadleaved coppice (27 ha).
The privately held forest areas have changed owners often up until the present, which led to overexploitation of the fir tree. Today, the fir groves cover only a limited surface of the entire forest (17 ha). The remarkable vitality of Abies alba is evidenced in the archives ("young firs are swarming"), and today most of the woodlands are experiencing very active regeneration of fir. The major current landscape change is the spontaneous or artificial afforestation of agricultural lands since 1960-70, a consequence of their abandonment (Fig. 3).

\section{Materials and methods}

\subsection{Pedoanthracology analysis}

In order to get an overall history as well as spatial interpretation within the valley, a multi-sampling strategy was used to determine the local diversity at both the bioclimatic and anthropic management level. Two sampling points were located in the pedological context in woodlands of the south-facing (Montbrun 3) and northfacing (Montbrun 2) slopes of the valley (Fig. 1). A third sampling point was selected in a pedosedimentary context (Montbrun 1), in the alluvial terrace that fills the lower part of the valley. The objective was to obtain a representative sampling of vegetation of the whole watershed, covering current forested areas and agricultural fields(see Fig. 3).

The samples were extracted by digging three holes $190 \mathrm{~cm}$ deep for sedimentary samples and $110 \mathrm{~cm}$ and $100 \mathrm{~cm}$ deep for forest soils. Isolation, quantification, and identification of soil charcoals were based on a procedure previously published by Talon et al. (1998). Anthracomass was calculated on the basis of the mass of charcoal fragments larger than $0.8 \mathrm{~mm}$.

Taxonomic analysis was done for a maximum of 100 charcoal pieces (including indeterminate charcoal and vitrified charcoal) per layer of sampling when the charcoal quantity allowed. To avoid bias due to possible variability in fragmentation, depending on the type of anatomic structure and/or state of conservation, the 100 charcoal pieces were randomly selected and equitably divided into three

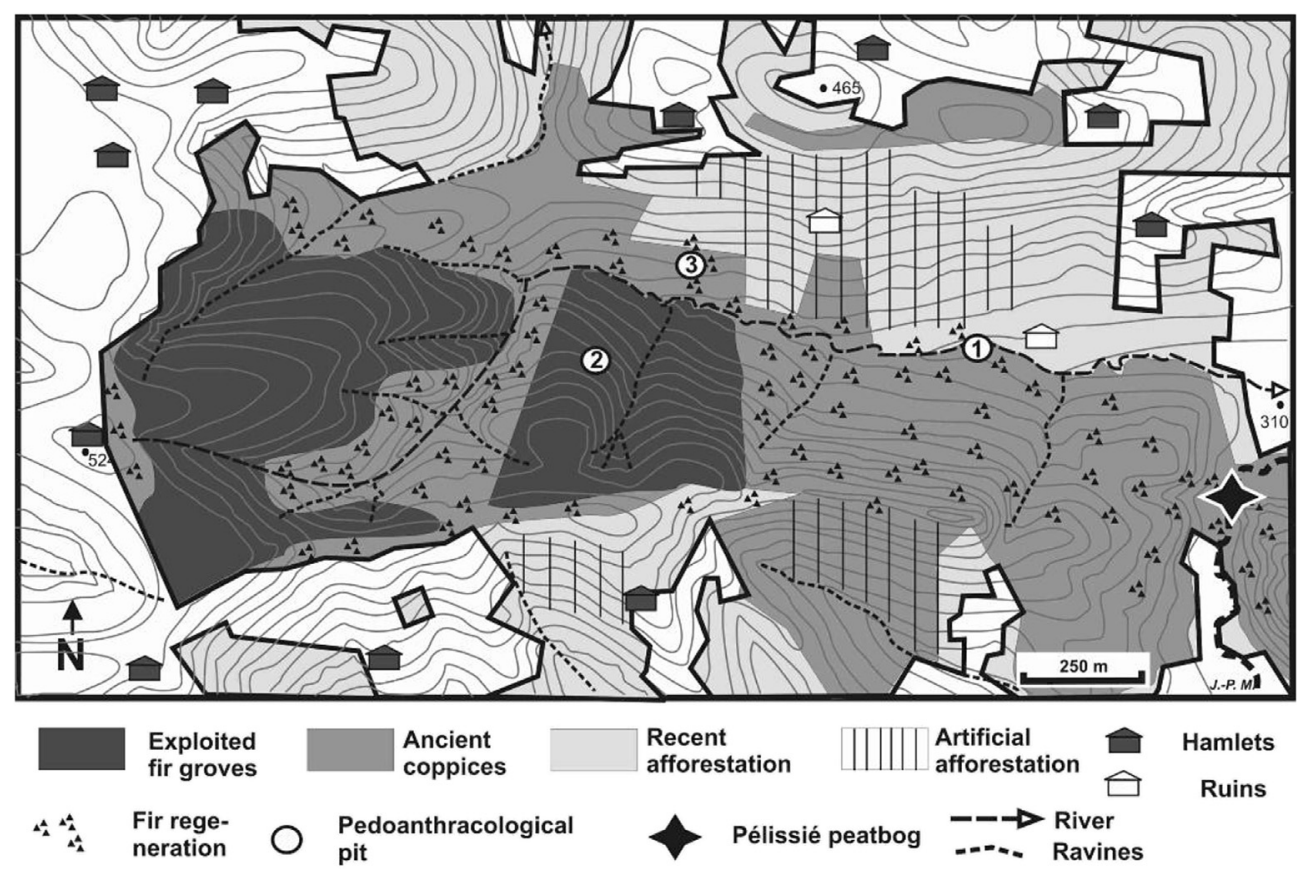

Fig. 3. Current vegetation of the forest of Montbrun (aerial photographs and ground plotting). 


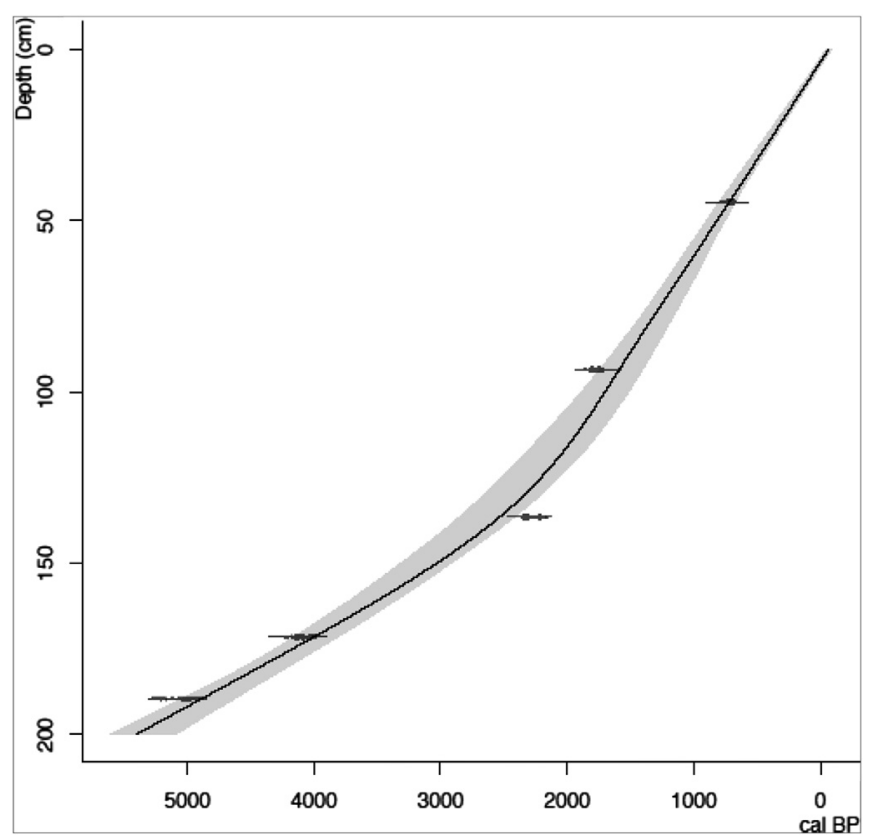

Fig. 4. Age-depth model of the Pelissie sequence based on smooth spline age-model with a default smoothing 0.3 .

classes by size: $>5 \mathrm{~mm}, 5-2 \mathrm{~mm}$, and $2-0.8 \mathrm{~m}$ when the quantity of each charcoal size allowed it. To identify the charcoal fragments $(\mathrm{n}=1864)$, we used an Olympus BX 51 episcopic microscope $(100 \times$, $200 \times$, and $500 \times$ ). Taxa were determined with the help of an atlas of the anatomy of woody plants (Schweingruber, 1982, 1990; Vernet et al., 2001) and the charred wood reference collection of the GEODE laboratory (University of Toulouse II-Jean-Jaurès).

From the group of separated charcoals, a total of 15 samples were selected for carbon-14 dating by Accelerator Mass Spectrometry (14C-AMS) in the Beta Analytic laboratory (Miami, Florida, USA) and Poznan Radiocarbon Laboratory (Poznan, Poland). The radiocarbon ages were calibrated using the Oxcal program, version 4.2, based on the Intcal13.14c database (Reimer et al., 2013) and with a standard deviation of 2 sigma ( $95 \%$ probability).

\subsection{Palynology methods}

One core sample (PELIS) was taken with a Russian peat sampler (GIK type, $50 \mathrm{~cm}$ length, $8 \mathrm{~cm}$ in diameter). The sampling point was located at $312 \mathrm{~m}$ a.s.l. in a small peat area at Pélissié, an alluvial terrace along the Paris stream. Four overlapping $50-\mathrm{cm}$ cores were obtained. Five vegetal macroremains samples were selected for 14C-AMS dating (Table 1). The age model was developed using Clam 2.2 and R 2.11.0 (Blaauw, 2010). We chose a smooth spline age-model with a default smoothing of 0.3 (see Fig. 4).

Table 1

Radiocarbon dates for the sediment cores from the Pélissié peat bogs; calibration: Clam 2.0 model (Blaauw, 2010) with calibration curve IntCal13.14C $(C C=1)$ from Reimer et al. (2013).

\begin{tabular}{llrll}
\hline Sample & Laboratory code & \multicolumn{1}{c}{ Age ${ }^{14} \mathrm{C}$} & Material & Calibration (cal BP) \\
\hline Pelis 44-45 & Beta-323064 & $790 \pm 30$ & Wood & $672-760$ \\
Pelis 93-94 & Beta-323061 & $1840 \pm 30$ & Wood & $1709-1864$ \\
Pelis 136-135 & Beta-347643 & $2290 \pm 30$ & Wood & $2164-2353$ \\
Pelis 171-172 & Beta-339973 & $3740 \pm 30$ & Needle fir & $3985-4223$ \\
Pelis 189-190 & Beta-339974 & $4430 \pm 30$ & Needle fir & $4876-5274$ \\
\hline
\end{tabular}

For pollen analysis, $1 \mathrm{~cm}^{3}$ subsamples were taken at $5 \mathrm{~cm}$ intervals. Pollen preparation followed standard methods using treatment with $10 \% \mathrm{KOH}$ ( $35 \mathrm{mn}$ ), $\mathrm{HF}(24 \mathrm{~h}$ ), sieving at $250 \mu \mathrm{m}$ and acetolysis, and final mounting in glycerin (Faegri and Iversen, 1989). A minimum of 400 terrestrial pollen grains were counted in each sample.

Alnus and Cyperaceae were excluded from the pollen sum to avoid over-representation of aquatic and local taxa. All pollen types were defined according to Faegri and Iversen (1989) and Beug (2004), although some identification required the use of pollen atlases (Reille, 1992-98) or pollen reference collections from the GEODE laboratory (University of Toulouse II-Jean-Jaurès).

\section{Results}

\subsection{Pedoanthracology}

Soil sample analysis showed that anthracomass was present at all sampling points, but with high variability in the results (Fig. 5). In the Montbrun-Bocage forest, we observed a specific anthracomass of about $1500 \mathrm{mg} / \mathrm{kg}$ at the Montbrun 1 sampling site, localized in the lower layers of the profile but above the gravel layer. This was the highest value found. In the Montbrun-Bocage forest, we observed a specific anthracomass of about $1500 \mathrm{mg} / \mathrm{kg}$ at the Montbrun1 sampling site, localized in the lower layers of the profile but above the gravel layer. This was the highest value found. Below the gravel layer, we found a minimal quantity of charcoals. At higher levels, the charcoal mass decreased toward the surface, stabilizing at about $200 \mathrm{~g} / \mathrm{kg}$ at $70 \mathrm{~cm}$ depth. At the two sampling points on the forest soil, the highest numbers of charcoals were concentrated at the two layers closest to the surface $(0-40 \mathrm{~cm}$ depth). Anthracomass levels were lowest at the deepest strata. The lowest values at these sites were observed at Montbrun3, where they never exceeded $65 \mathrm{mg} / \mathrm{kg}$ and at a certain intermediate level the charcoals disappear, and at Croix3, where we found values below $10 \mathrm{mg} / \mathrm{kg}$. It is interesting that these very low values correspond to south-facing slope sites.

The 1895 charcoals identified contained a large variety of arboreal taxa in the valley (see Table 2 ), with the majority being Fagus sylvatica, Quercus/Castanea, and Abies. These taxa appeared at all sampling points. Another species with a larger presence in the profiles was Juniperus, followed by smaller amounts of arboreal taxa related to riverbanks (Alnus, Salix, Populus) and heterogeneous taxa such as Corylus, Prunus, Maloideae, Rosa, and Ulmus.

At Montbrun1, we identified Abies at almost all levels of the profile, although its presence was minimal, reaching $20 \%$ of the identified anthracomass only at the base of the profile. The Quercus/ Castanea group constituted the majority of this profile and Fagus has an important but variable role. The presence of riverbank species such as willows differentiates this sampling point.

At Montbrun 2 Abies constituted about $40 \%$ of the anthracomass at the base and Quercus and Fagus took over at higher levels. In this transition, Juniperus eventually became the major species, with values of about $20 \%$ at level IV.

The sampling point on the sunny slope, Montbrun3, was notable for the low quantity of anthracomass, the high level of vitrification, and the poor condition of the anatomic structure of the charcoal. At the higher levels we identified forest species common to all three sampling points (Abies or Quercus but not Fagus), and shrub taxa (Maloideae) present only in this profile.

The 15 radiocarbon dates ranged from the Neolithic to Modern (Table 3). Following the radiocarbon chronology, fire episodes can be dated during early Neolithic (6900-6300 cal BP), Bronze Age (3900-3200 cal BP), Antiquity-Early Middle Age (1850-1600 cal 
Table 2

Results per sample point and point level of taxonomic identification (mg).

\begin{tabular}{|c|c|c|c|c|c|c|c|c|c|c|c|c|c|c|c|c|c|c|c|c|c|c|c|}
\hline & & $\begin{array}{l}\text { Abies } \\
\text { alba }\end{array}$ & $\begin{array}{l}\text { Fagus } \\
\text { sylvatica }\end{array}$ & $\begin{array}{l}\text { Quercus } \\
\mathrm{sp}\end{array}$ & $\begin{array}{l}\text { Quercus/ } \\
\text { Castanea }\end{array}$ & $\begin{array}{l}\text { Alnus } \\
\text { sp }\end{array}$ & $\begin{array}{l}\text { Juniperus } \\
\text { sp }\end{array}$ & $\begin{array}{l}\text { Betulaceae } \\
\text { (Corylus/ } \\
\text { Alnus) }\end{array}$ & Corylus & Salix & Populus & $\begin{array}{l}\text { Salix/ } \\
\text { Populus }\end{array}$ & Prunus & Pinus & Ulmus & $\begin{array}{l}\text { Maloideae/ } \\
\text { Rosaceae }\end{array}$ & $\begin{array}{l}\text { Rosa } \\
\text { sp }\end{array}$ & Conifer & $r$ Angiosperm & Vitrified & Inidentified & $\begin{array}{l}\text { Total } \\
\text { analysed } \\
\text { (mg) }\end{array}$ & $\begin{array}{l}\text { Total } \\
\text { analysed } \\
\text { (n) }\end{array}$ \\
\hline \multirow{11}{*}{ 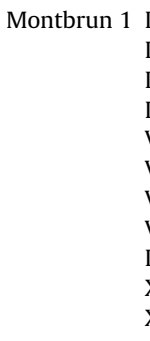 } & & 2 & 545 & 75 & 160 & & 122 & 2 & & 41 & 2 & & & & & & & 80 & 8 & 69 & 39 & 1145 & 100 \\
\hline & II & 26 & 379 & 254 & 151 & & 17 & 21 & 8 & & 2 & & & & & & & & & 52 & 37 & 947 & 101 \\
\hline & III & 10 & 148 & 416 & 334 & & & & & & & & & & & & & & & 37 & 93 & 1041 & 100 \\
\hline & IV & 9 & 46 & 198 & 187 & & 6 & & & & & & & 3 & & & & & 2 & 20 & 43 & 541 & 100 \\
\hline & $\mathrm{V}$ & 6 & 9 & 153 & 165 & & & & & & 2 & & & & & & & & & 12 & 63 & 410 & 100 \\
\hline & $\mathrm{VI}$ & 20 & 177 & 215 & 243 & & & & & & & & & & & & & & 3 & 30 & 16 & 704 & 121 \\
\hline & VII & 8 & 76 & 434 & 541 & & & & & & & & & & & & & & & 3 & & 1062 & 123 \\
\hline & VIII & & 867 & 1260 & 933 & & & & & & & & & & & & & & & 88 & 98 & 3246 & 139 \\
\hline & IX & 16 & 2032 & 805 & 856 & 422 & & 30 & & & & & & & 3 & & & 7 & & & 18 & 4189 & 190 \\
\hline & $\mathrm{x}$ & 18 & 55 & 107 & 26 & & 8 & 8 & 3 & & & & & & & & & 6 & & 134 & 8 & 373 & 106 \\
\hline & XI & 17 & & 9 & 32 & & 3 & & & & & & & & & 13 & & 4 & 5 & 3 & & 86 & 52 \\
\hline \multirow[t]{5}{*}{ Montrun 2} & V & 8 & 559 & 188 & 243 & & 21 & & & & & & & & & & & 11 & 36 & 94 & & 1160 & 105 \\
\hline & IV & 184 & 451 & 425 & 286 & & 42 & & & & & & 27 & & & & & & 9 & 34 & 99 & 1557 & 100 \\
\hline & III & 25 & 184 & 402 & 70 & & 11 & & 5 & & 11 & & & & & & & 10 & 13 & 2 & 30 & 763 & 108 \\
\hline & II & 79 & 31 & & 53 & & 33 & & & & & 2 & & & & & & 2 & & 9 & 5 & 214 & 102 \\
\hline & I & 136 & 16 & & 20 & & 4 & & 3 & & & 7 & & & & 4 & 4 & 82 & & 31 & 7 & 314 & 101 \\
\hline \multirow{6}{*}{ Montbrun 3} & I & 2 & & 135 & 45 & & & & & & & & 9 & & & & & & & 2 & & 193 & 78 \\
\hline & II & 7 & & 3 & 1 & & 2 & & & & & & 3 & & & 3 & & & 6 & & 8 & 33 & 55 \\
\hline & III & & & & & & & & & & & & & & & & & & & 1 & 1 & 2 & 4 \\
\hline & IV & & & & & & & & & & & & & & & & & & & & & & 0 \\
\hline & $\mathrm{V}$ & & & & & & & & & & & & & & & & & & 1 & 1 & & 2 & 3 \\
\hline & VI & & & & & & & & & & & & & & & & & & 3 & & 4 & 7 & 7 \\
\hline
\end{tabular}



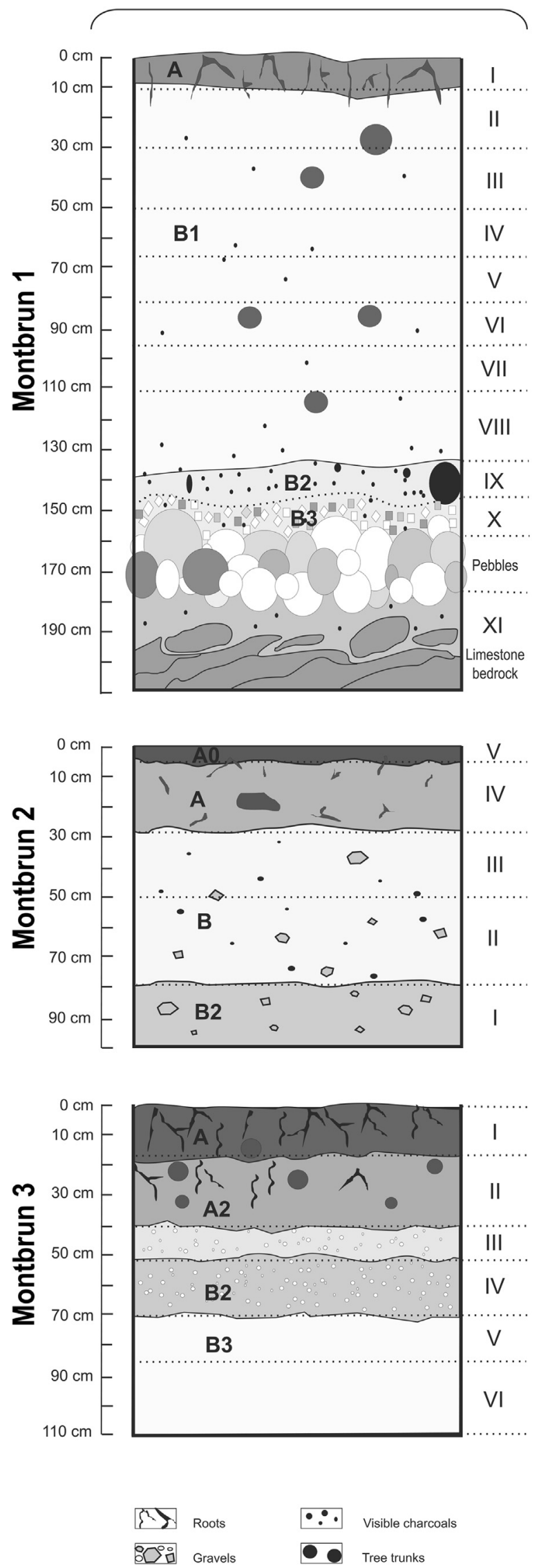

b
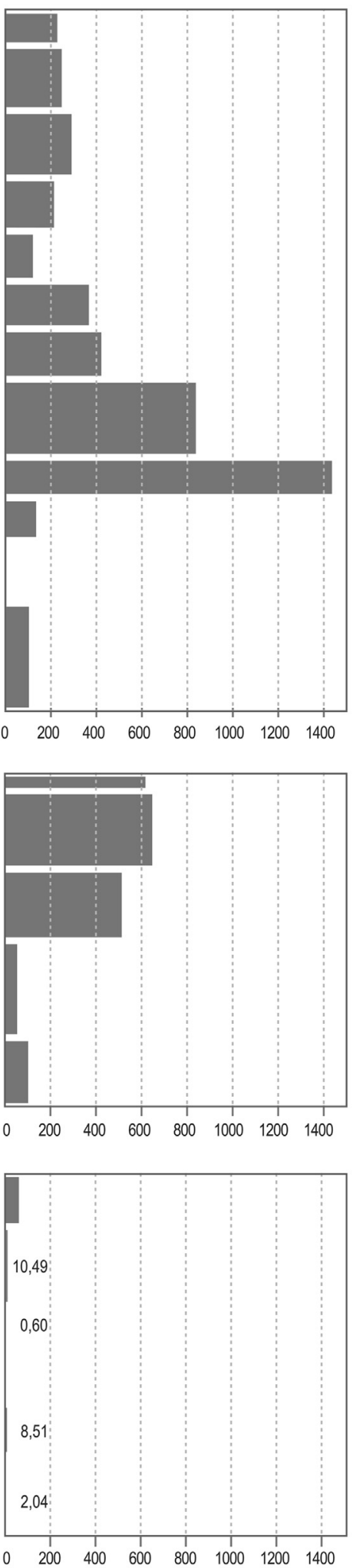

$\begin{array}{ll}\text { Abies alba } & \rightleftharpoons \text { Quercus/Castanea } \\ & \text { Fagus silvatica }\end{array}$
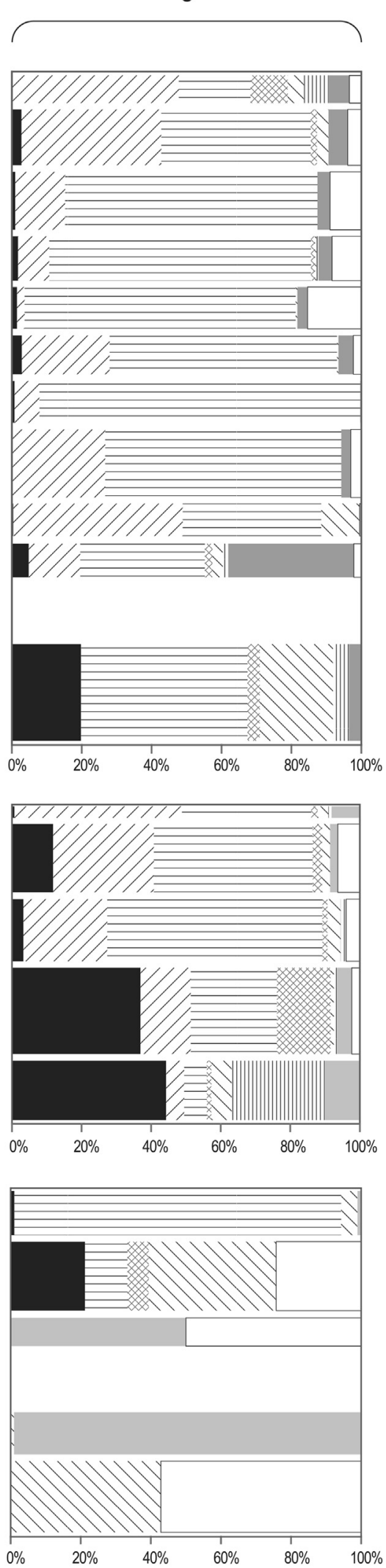

C

$\begin{array}{ll}\square .7 \text { Other broad leaved } & \square \text { Vitrified } \\ \square D \text { Other conifer taxa } & \text { No identified }\end{array}$

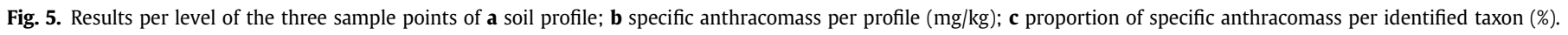


BP), and Medieval-Modern (900-300 cal BP) periods. The last period, with the largest number of dates (9), can be subdivided into the 10th-14th centuries and 15th-17th centuries (Fig. 6).

Table 3

Radiocarbon dating of soil charcoals, classified by site and depth calibrated using the calibration curve of OxCal 4.2 (Bronk Ramsey, 2009).

\begin{tabular}{llllcc}
\hline $\begin{array}{l}\text { Sample } \\
\text { point }\end{array}$ & $\begin{array}{l}\text { Deep } \\
(\mathrm{cm})\end{array}$ & Code & $\begin{array}{l}\text { Laboratory } \\
\text { code }\end{array}$ & Age ${ }^{14} \mathrm{C}$ & $\begin{array}{l}\text { Calibrated } \\
\text { date (cal BP) }\end{array}$ \\
\hline Montbrun 1 & $30-50$ & M1IIFAGUS & Poz-60280 & $\begin{array}{c}300 \pm 30 \\
\text { BP }\end{array}$ & $461-296$ \\
& & & & $760 \pm 30$ & $731-666$ \\
Montbrun 1 & $75-95$ & M1VIABIES & Poz-60281 & 760 & \\
Montbrun 1 & $50-70$ & M1IVABIES & Poz-60282 & $340 \pm 30$ & $481-311$ \\
Montbrun 1 & $95-110$ & M1VIIQUERCUS & Poz-60287 & $810 \pm 40$ & $790-674$ \\
Montbrun 1 & $135-145$ & M1IXABIES & Beta-323065 & $870 \pm 30$ & $905-701$ \\
Montbrun 1 & $145-160$ & M1XABIES & Beta-337801 & $3560 \pm 30$ & $3965-3724$ \\
Montbrun 1 & $145-160$ & M1XFAGUS & Beta-337802 & $670 \pm 30$ & $677-559$ \\
Montbrun 1 & $180-200$ & M1XIABIES & Beta-337803 & $1850 \pm 30$ & $1865-1715$ \\
Montrbun 1 & $180-200$ & M1XIQUERCAST & Beta-337804 & $850 \pm 30$ & $898-690$ \\
Montbrun 2 & $10-30$ & M2IVABIES & Poz-60283 & $310 \pm 30$ & $465-301$ \\
Montbrun 2 & $30-50$ & M2IIIQUERCUS & Poz-60284 & $295 \pm 30$ & $460-291$ \\
Montbrun 2 & $50-80$ & MONTBRUN2-1 & Poz-56965 & $1770 \pm 35$ & $1814-1573$ \\
Montbrun 2 & $80-100$ & MONTBRUN2-2 & Poz-56966 & $1780 \pm 25$ & $1810-1618$ \\
Montbrun 3 & $20-40$ & M3IQUERCUS & Poz-60285 & $5820 \pm 110$ & $6905-6356$ \\
Montbrun 3 & $70-83$ & M3VABIES & Poz-60286 & $3170 \pm 50$ & $3550-3246$ \\
\hline
\end{tabular}

In the pedosedimentary profile of Montbrun1, we found a broad chronological span, but on the valley slopes we observed temporally opposite dates. Montbrun3 offered the oldest dates (Neolithic and Bronze Age) and Montbrun2 yielded only charcoals from Antiquity and the Medieval period.

\subsection{Palynology}

The pollen diagram (Fig. 7) allowed us to describe the different zones and observe the major phases of the site's vegetation history.

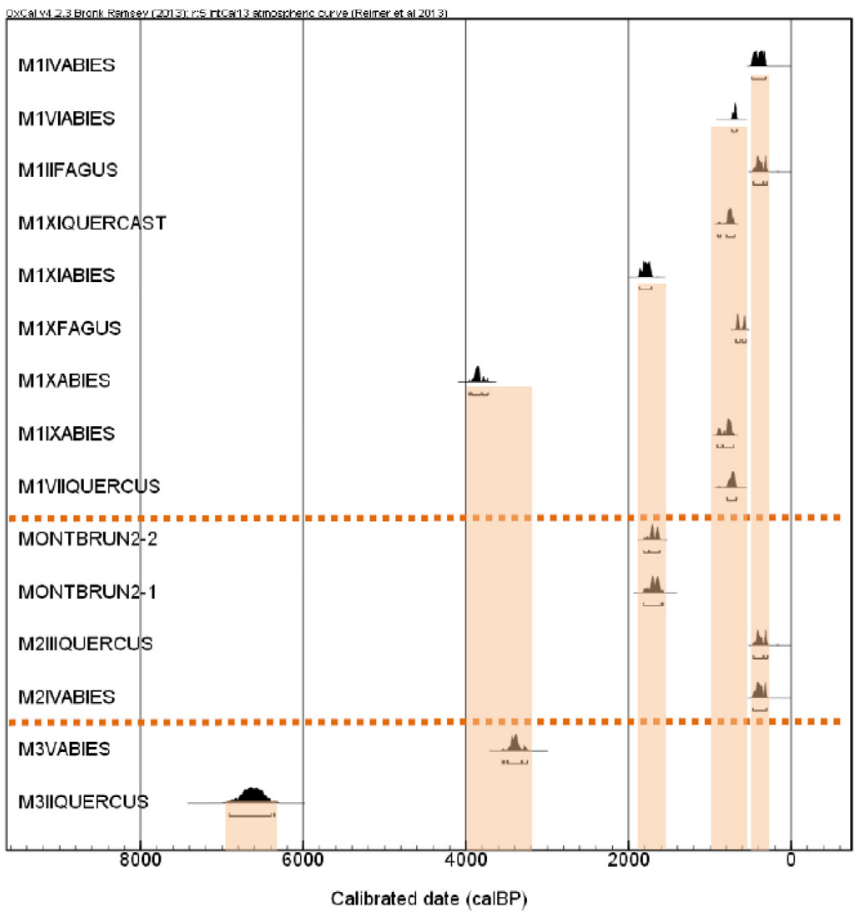

Fig. 6. Temporal distribution of 15 dated charcoals.
Several arboreal species are characteristic of the base of the pollen diagram (Phase [P]-1, 5300-4100 cal BP). Abies played a key role in this period, and these values are the highest in the profile. Forest changes defined phase P2 (4100-2900 cal BP). As Abies declined, Fagus arrived and quickly gained importance. Other species related to humid environments (Fraxinus, Corylus, Alnus) also increased during this period. Relative stability reigned during P3 and P4 (2900-1800 cal BP), with the stabilization or return of most of the arboreal species. This trend changed at the end of $\mathrm{P} 4$ and beginning of P5 (1800-1200 Cal BP), when all arboreal species except Corylus decreased dramatically. At the same time, herbaceous plants such as Poaceae or Plantago increased. This is also the point at which we began to find significant levels of Cerealia and Secale. The last major period of change was observed during P5b (1200-1000 cal BP) and P6 (1000-400 cal BP). The arboreal record generally decreased and only Juglans and Castanea escaped the trend. At this point, indicators of anthropic activity related to agriculture or grazing reached maximum values.

\section{Discussion}

The major result obtained in the present study was that pedoanthracological and palynological data prove the natural origin of the fir forests of Montbrun, and thereby contradict the hypothesis of the anthropogenic origin of this forest, which supposedly was planted during the Medieval period. In the Montbrun 1 pedoanthracological record, the oldest Abies charcoals were dated from the Bronze Age (3965-3724 cal BP) and at the lower level of the pollen diagram (5300 cal BP) Abies contributed a large part of the arboreal pollen. In addition, we know it was a local forest because fir needles and stomata were found in the same part of the sedimentary column. Nonetheless, this natural origin of the fir forest is not disconnected from a long history of human activity in this area.

\subsection{Palaeoenvironmental history of the Montbrun region}

The earliest charcoal dating is from the Neolithic (6905-6356 cal BP), but it is impossible to know if it results from an anthropic process or not. However, palaeoecological research in the central Pyrenean foothills (Reille and Andrieu, 1995; Rius et al., 2009) has shown clear indications of initial agricultural activity and intensification of grazing activity during this period. In addition, some authors have defended a synchronicity of fires at the macro level during the first half of the Holocene that could be due mainly to climate forcing (Rius et al., 2011, 2012). The fact that the dated charcoal was found only at one place in the valley and on the sunny slope leads us to consider a possible human action related to taking advantage of the location with the best microclimate in the valley for crops or livestock activities.

The pollen diagram provides data beginning from $5300 \mathrm{cal} \mathrm{BP}$, showing a mixed woodland of Quercus, Corylus, or Tilia, where Abies was important at the local scale. The pollen concentration and the presence of stomatas and macroremains suggest a local fir forest.

However, this forest vegetation began to change slightly towards 4300 cal BP and more intensely after 3800 cal BP. At the forest level, Abies began to decrease at the same time that Fagus began its expansion. Simultaneously, species such as Alnus and Corylus also increased their presence. Despite a climatic change that occurred throughout the Pyrenees at this time, linked to increased humidity (Jalut et al., 1996), the increase in these species is more related to the presence of Riparian vegetation in the sampling area or to anthropic clearings than to climate change.

There were other changes during this period. The charcoals on the valley floor and the sunny slope indicate a fire phase from 3900 


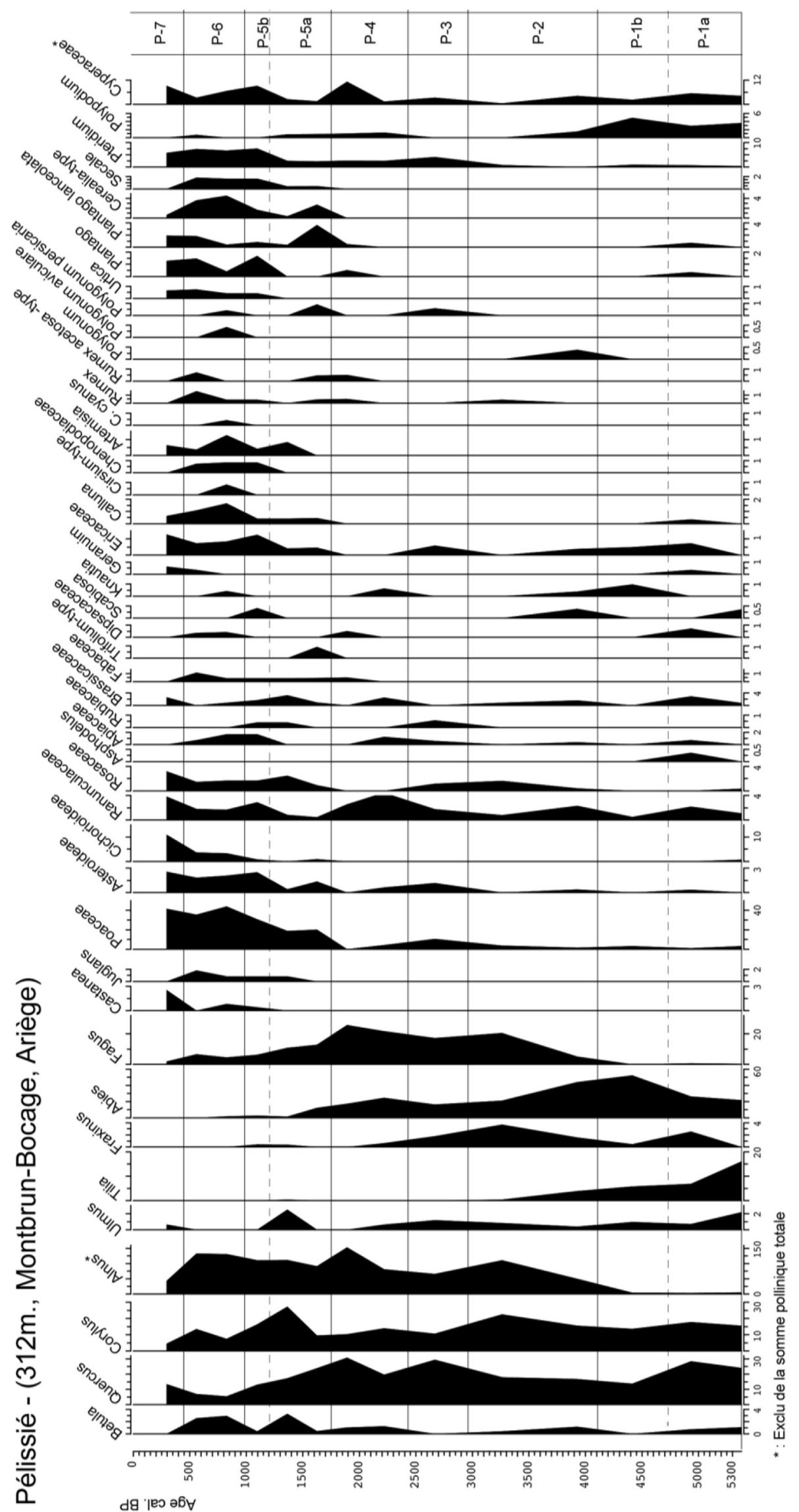

Fig. 7. Main taxa pollen diagram from the Pélissié peat bog. 
to 3200 cal BP. These fires contrast with the increasing humidity, and were more likely induced by increasing human activity in the valley, indicated by the arrival in the pollen diagram of Rumex or Polygonum, which are related to grazing activities. The soil charcoals that were dated confirm this anthropization of the area, with clear impacts on Abies, the species represented in the two charcoals dated for this period. The question remains: Is the shift from Abies to Fagus natural and due to climate change or the product of some human impact? It is difficult to determine where natural causes end and human causes begin in the landscape changes during the second half of the Holocene. Many authors (Keller et al., 2002; Van der Knaap et al., 2004; Wick and Möhl, 2006; Kozáková, 2011) deduce a natural-climatic trend in the fir-beech relationship, which was affected by clearings maintained in order to carry out practices such as slash-and-burn agriculture or grazing activities. Other researchers (Kenla and Jalut, 1979; Jalut et al., 1982, 1988; Galop et al., 1994; Galop, 2005) have shown that the climate in the Pyrenees was an important factor for the development of beech forest, but they also demonstrate the human influence in the strong decline in fir forests. In this period, fir was totally destroyed by overexploitation in some eastern and central Pyrenean valleys (Galop and Jalut, 1994; Bonhôte, 1998).

Around $2700 \mathrm{cal} \mathrm{BP}$, the pollen record shows us a time of change after a period of forest recovery. This change intensified during Antiquity. By about 2000 cal BP, the first agricultural indicators appeared and we could see clear effects of anthropization on the forests. All arboreal taxa decreased, except Corylus and Juglans, which first appeared at that point. During Late Antiquity, the simultaneous growth of anthropogenic indicators (Plantago lanceolata, Rumex, Asteraceae), cereals (Cerealia, Secale) and cultivated trees (Juglans), as well as the increase in Poaceae, provide strong evidence of increasing agrarian uses.

The soil charcoals confirmed this change and its effects on the fir forest. At the lower level (NI) of Montbrun2 (Fig. 5), fir was dominant; at the higher level (NII) it decreased, to be replaced by beech and other species indicative of forest clearings. Juniperus and Abies charcoals were dated at these levels (1800-1600 cal BP), which correspond precisely to the Roman period. Changes and decline in fir forests at that time were not a local phenomenon, occurred at various points in the mountains of south Europe and Pyrenees. The Alps are a clear example of the strong human pressure on the forests during the Roman period (Küster, 1994; Nakagawa et al., 2000; Ortu et al., 2003; Muller at al., 2007). According to the palaeobotanical records in the Pyrenees, this pressure was unequal in the different valleys (Esteban et al., 2003; Galop, 2005; Ejarque et al., 2009; Cunill, 2010; Galop et al., 2013). Part of this irregular distribution of human pressure was due to the localization of mining activity on both sides of the mountain range (Dubois, 1996, 2000; Camareo et al., 1998; Galop, 2005). The proximity of important Roman copper mines in the north Pyrenean Piedmont (Dubois and Guilbaut, 1982) offers a possible explanation for the agricultural intensification in the Montbrun area.

During the early Medieval period, human activity intensified. Pollen indicators show that the agrarian expansion that began during Antiquity underwent dramatic change. Arboreal taxa clearly declined, and at this point fir nearly disappeared from the pollen diagram. Charcoals dated to later periods show that the fir persisted, although to a lesser degree, in the vegetation assemblages of Montbrun and did not completely disappear from the north Pyrenean foothills. The acceleration of the anthropization of the Pyrenean mountains seems to be generalized in this period (Pèlachs, 2005; Rius at al., 2009; Bal, 2011; Galop et al., 2013; Rendu, 2013).

The accelerating human activity continued without pause during the late Middle Ages, with increasing and expanding indicators of agro-pastoral activity. The numerous charcoals dated to this period emphasize this landscape change and the expansion of fields and pastures. Nine of the 15 charcoals belong to this period and four of them are remains of fir. It is the period of strongest anthropization, which can be identified in most palaeoecological or historical sources in the Pyrenees. French demographic historians called this period "the full world" (Dubois, 1988) due to the high population density.

At this point, we must pose the question of which anthropic (land management) and/or environmental (climate, sunshine, soil) elements allowed the fir tree to survive to the present here, despite the same periods of maximum anthropization that the firs of the nearby lowlands did not survive. This is a topic for further research in the zone. The documentary information found to date (Cunill et al., 2014) does not provide accurate information about forest management until the 17th century. In 1667, Louis de Froidour "Great Commissioner of Forest Reformation", described the nearby fir forest of Sainte-Croix-Volvestre as degraded and emphasized the need to preserve and increase fir forests, a useful resource of interest for the kingdom.

\subsection{Inside the forest of Montbrun}

The analysis of soil charcoals allowed us to study the woody assemblages at a more local scale, providing information on the different aspects of the valley slopes. Topography, climate, and land management were clearly variable and important in the configuration of the landscape, and our charcoal record provides good evidence of this situation.

The sampling point designated for analysis of the pedosedimentary zone downstream of the valley provided information about the vegetation dynamics but also about the geomorphologic dynamics. The sedimentary profile of Montbrun 1 is defined by a pedological horizon $20 \mathrm{~cm}$ thick surmounting a $120 \mathrm{~cm}$ sedimentary settling (Fig. 5). At the base of this unit, there is a layer of decimetric pebbles and centimetric gravels supporting the river's course during wet seasons. Below this layer, grey clays rest on a limestone substratum. These deeper layers, the fruit of the first phases of erosion, contained charcoals of varying ages, ranging from 3500 cal BP to 670 cal BP. This indicates the beginning of major processes of erosion during the deforestation of the valley in the Middle Ages. The soils and colluvium of the whole watershed were reworked, including materials from the summit plateaus. Our discovery of a charcoal from the Medieval period under the cemented pebble layer confirms the Medieval chronology of this process. Dates from upper layers showed a chronological sedimentation with 12th and 13th century charcoals at levels VI and VII $(80-110 \mathrm{~cm})$ and 16 th and 17th century charcoals at levels IV and II $(10-70 \mathrm{~cm})$. Altogether, these data indicate that $120 \mathrm{~cm}$ of colluvial sediments were deposited during the centuries following the medieval erosion, lasting at least until the end of the 17th century. Even if there were forest fires or pasture burnings during the Bronze Age, these would not have caused the massive soil erosion in the river basin. The fires and human activities in general, however, did have a major impact on the woodlands in the Late Middle Ages, intensifying after the 10th and 11th centuries and until the 15 th century. We have many dates and pollen diagram indicators of human activity from this period; the erosion that deposited grey clays, large pebbles, gravels, charcoals, and large tree trunks also occurred during this period. This colluvial process after a major land clearing has been well documented and studied in Central Europe (Bork and Lang, 2003; Bork et al., 2009; Dreibrodt et al., 2009). Following this episode, a stabilization of sediments that constitutes the $120 \mathrm{~cm}$ unit occurred after the 14th-15th century. These materials came from the rapid, superficial erosion of the slopes that could have been caused by burning of pastures, 
cultivation of unstable terraced fields on the slopes, clear cutting, forest fires, etc. In the final period, soil erosion stopped and the small creek incised the whole sedimentary stratum.

Another important highlight of this profile is that Abies charcoals were found throughout. Although it is true that their quantity is small, their presence is constant. The oldest and newest dates in this profile were Abies, which illustrates the historical existence of this species at the heart of the Montbrun region.

The Montbrun2 sampling point shows that fir was of great importance in the composition of the forest, as more than $40 \%$ of charcoals at the base were Abies. At the upper level, other species appear that mark the clearing of the woodland (e.g., Juniperus, Corylus, Prunus, Populus) and Abies never recovered its higher percentages at any of the upper levels. The dates (Abies and Juniperus) from lower levels are from Antiquity, which corresponds to the time of fir decline on this site. At the upper levels we find the effects of this decline from the 15th to 17th centuries, the most recent periods for which we recorded dates.

The sunny slope offered some surprising results. At Montbrun3, an old, private woodland located close to fallowed lands and recent plantations, we expected to see a high percentage of charcoals as a result of forest clearing or slash-and-burn agriculture. However, the anthracomass we found was minimal and even non-existent at one of the levels. Despite this lack of charcoals, the result is valuable in terms of information about the sunny slope. For example, the Bronze Age $(3170 \pm 50$ cal BP) dating in the lower level confirmed that the fir tree extended indifferently on all the slopes of the basin after the Neolithic, and likely until the Middle Ages. Today, fir is growing on the slope and abundant seedlings are visible in the undergrowth. In addition, the oldest evidence of forest fire (6900-6300 cal BP) was found in this place. The currently available data in Montbrun do not allow us to affirm that we have evidence of human impact, but other palaeoenvironmental data from the Pyrenean Piedmont (Rius et al., 2009) indicate this is a plausible hypothesis. In any case, this dating indicates an early sign of sunny slopes disturbance. There are several possible explanations for the absence of more recent dated fragments. First, we found only very small charcoal fragments, for the most part impossible to use for AMS carbon dating. Therefore, more recent charcoals could possibly have been present but we could not date them because of their size ( $<10 \mathrm{mg}$ ). Secondly, intense medieval or postmedieval erosion could have taken away the soil and the charcoals it contained. Finally, we hypothesize that, from the Bronze Age until very recent periods, this was a zone without a major impact from fires, because these spaces remained open clearings without woody vegetation after the Bronze Age. This hypothesis agrees with observations made about the end of the Iron Age (Rius et al., 2009). In conclusion, this absence of dated charcoals raises questions about very specific spaces, such as the sunny slopes of Pyrenean valleys.

The chronological stratification of soil charcoals is always a topic of discussion in any pedoanthracological study. Many previous studies have shown that we cannot simply assume that charcoal fragments will be time-stratified in the soil where we find them (Carcaillet, 2001; Bal, 2006). Studies in alpine and subalpine valleys of the Alps and Pyrenees reflect this reality (Carcaillet, 2001; Cunill et al., 2012, 2013), but others carried out in deeper soils have shown that there may be a certain kind of stratification. For example, Carcaillet and Talon (1996) suggest a possible interpretation of "assemblages" or collections of charcoals in the soil profile. The sampling points in the Montbrun forest soil were chronologically stratified, and we can infer certain logical assemblages linked to forest succession. In the pedosedimentary soil of Montbrun, the chronology follows a logical connection with the sedimentation process. Early in the colluvial process, after opening up the area, erosion dragged with it a great quantity of charcoals from the different periods represented in the soils of the river basin. Later on, constant, gradual erosion continued to deposit the charcoals chronologically. In any case, we must always question the relationship between the chronology and the locations of charcoals if we wish to understand how soil functions and how pedoanthracological data should be interpreted.

\subsection{Biogeography and past, present, and future of Abies alba in the Pyrenees}

Confirmation of the presence of Abies alba at low altitudes in the foothills of the northeast Pyrenees contributes valuable information to our knowledge of the expansion of this species in the Pyrenees during the Holocene. From the palaeoecological data, we know that fir colonization in the Pyrenees during the Holocene occurred gradually, from east to west, beginning with the onset of colonization in various geographical areas (Mardones and Jalut, 1983; Pèlachs, 2005). A first phase of colonization has been documented between 9500 and $8000 \mathrm{cal} \mathrm{BP}$ in the eastern part of the north slope of the Pyrenees (Jalut, 1974; Reille and Loewe, 1993; Esteban et al., 2003). Several thousand years later, the first Abies pollen data appear in the central part of the Pyrenees (6500-5000 cal BP) (Jalut, 1974; Jalut et al., 1988). The third and final phase is the arrival of fir in the far western Pyrenees (Irati), where it is clearly present $650-500$ cal BP (Galop, unpub. data).

If we focus on the presence of Abies at low altitudes in the Pyrenees massif, the data are scant. Those from Volvestre provide the only evidence of its abundance in the northern foothills of the Pyrenees east of the Garonne river. Pollen data from sampling points in the western foothills, Gabarn (Rius et al., 2009), Col d'Ech (Rius et al., 2012), and Cuguron (Galop et al., 2000) clearly show the absence of fir below $600 \mathrm{~m}$ a.s.l. In addition, the Abies pollen frequencies recorded reflect only long distance transport. If we consider, along with this east-west expansion of Abies, the absence of pollen in the low mountains of the western zone and the Montbrun data, our only option is to support the hypothesis of a nucleus of Abies diffusion from the Mediterranean Pyrenees, where it was growing at low altitudes in 9000-8000 cal BP (Jalut, 1974; Reille and Loewe, 1993).

On the other hand, this difference between eastern and western populations of Abies alba on the northern slope of the Pyrenees is also supported by the genetic analysis performed by Fady and Musch (Gonin et al., 2012). Two genetic groups are described. One group consists of the populations from the Mediterranean Pyrenees to the Garonne valley, including the Volvestre fir woodlands. The second group extends from the Garonne valley to the Basque mountains (Irati). According to Fady, the most likely cause of this structure is the existence of at least two refuge areas, or two distinct groups of refuge areas, during the Wurmian glaciation. Each area would have evolved differently; together, they formed the basis of Abies postglacial recolonization in the Pyrenees.

The role of the Mediterranean lowlands as refuge areas is evident not only in the Pyrenean zone but also at the southern European level, as clearly shown in studies of the Italian peninsula (Terhürne-Berson et al., 2004; Liepelt et al., 2009). The palaeoecological data from Italy confirm the existence of firs in low-lying zones and areas near the sea during the mid-Holocene (Wick and Möhl, 2006; Colombaroli et al., 2007; Drescher-Schneider et al., 2007; Bellini et al., 2009). These populations at lower altitudes did not escape high levels of anthropization, an essential part of the reason we no longer find any residual population below $600 \mathrm{~m}$ altitude (Di Pasquale et al., 2014).

Palaeoecological data linked to topoclimatic modelling and to the study of residual populations lead us to question the paradigm of the fir as a species linked to cold and mountainous zones. Studies 
such as those by Tinner et al. (2013) and Di Pasquale et al. (2014) have shown the historical survival of firs in much more Mediterranean environments, far from the current paradigm. Residual populations such as the Volvestre forest provide current data that can help us understand the true ecological niche of Abies alba, which is much broader that what has been assumed to date. This new knowledge will allow us to anticipate the future dynamic of this species at this key time of climate change.

\section{Conclusion}

This research demonstrates the natural origin of the Volvestre fir woodlands, located at the lowest altitude in the Pyrenees. This clearly was not an isolated location; it provides evidence that fir had once successfully occupied all of the eastern Pyrenees lowlands, making these forests a natural heritage of the Pyrenees. Their natural origin is important at the biogeographic level because it provides information about the distribution and postglacial dynamics of fir populations secluded in Mediterranean areas during the mid and late-Holocene. It also confirms an ancient and important anthropization of the landscapes of the North Pyrenean foothills, an area where archaeological and palaeoecological data are very scattered, and sometimes non-existent. It is now possible to establish an initial chronology of human settlement and forest transformation; further studies are needed to validate the results.

The body of information available about the natural dynamics and the study of human intervention in this fir forest provides data that can help us understand the palaeoecological history of the forest. Even more important, it helps us understand the current Abies alba distribution in the Pyrenees and suggests possible future dynamics in the context of global climate change. The present study confirmed that pedoanthracology can be a useful methodology for interdisciplinary study of long-term dynamics of small-scale sites like ancient forests.

\section{Acknowledgements}

This study was funded by a research program, Caractérisation génétique et origine du Sapin pectiné (Abies alba Mill.) de SteCroix-Volvestre (Ariège) et du massif pyrénéen, coordinated by the French National Forest Private Property Center (Centre national de la propriété forestière and Ariège Natural Park (Parc naturel régional des Pyrénées Ariégeoises) and supported by the European Regional Development Fund (ERDF). Raquel Cunill has been supported by a Beatriu de Pinós Postdoc Fellowship (2010 BP-A 00171) provided by the Government of Catalonia. We would like to thank Jacques Hubschman, Gillian Gomez and Vanessa Py for their help in the field and their valuable viewpoints.

\section{References}

Alba-Sánchez, F., López-Sáez, J.A., Benito de Pando, B., Linares, J.C., Nieto-Lugilde, D. López-Merino, L., 2010. Past and present potential distribution of the Iberian Abies species: a phytogeographic approach using fossil pollen data and species distribution models. Diversity and Distributions 16 (2), 214-228.

Alba-Sánchez, F., López Sáez, J.A., Benito de Pardo, B., López Merino, L., 2009. Historia paleoecológica y modelo de idoneidad de Abies Alba Mill. en la cordillera Pirenaica. Pirineos 164, 93-116.

Bal, M.C., 2006. Constructions et dynamiques des espaces et des terrasses agropastoraux en zone intermédiaire des Pyrénées du Néolithique à nos jours (Cerdagne, Pays Basque et Pays de Sault), approche archéoenvironnementale par la pédoanthracologie. Phd dissertation. Laboratoire Geode, Université de Toulouse II. http://tel.archives-ouvertes.fr.

Bal, M.C., Pelachs, A., Perez-Obiol, R., Julia, R., Cunill, R., 2011. Fire history and human activities during the last 3300cal yr BP in Spain's Central Pyrenees: the case of the Estany de Burg. Palaeogeography, Palaeoclimatology, Palaeoecology 300, 179-190.

Bellini, C., Mariotti-Lippi, M., Montanari, C., 2009. The Holocene landscape history of the NW Italian coasts. The Holocene 19 (8), 1161-1172.
Beug, H.J., 2004. Leitfaden der Pollenbestimmung für Mitteleuropa und angrenzende Gebiet. Pfeil, München.

Blaauw, M., 2010. Methods and code for 'classical' age-modelling of radiocarbon sequences. Quaternary Geochronology 5, 512-518.

Blanco, E., Casado, M.A., Costa, M., Escribano, R., García, M., Génova, M., Gómez, A. Gómez, F., Moreno, J.C., Morla, C., Regato, P., Sáinz, H., 1997. Los bosques ibéricos. Una interpretación geobotánica. Editorial Planeta, Barcelona.

Bonhôte, J., 1998. Forges et forêts dans les Pyrénées ariégeoises: pour une histoire de l'environnement. PyréGraph.

Bonhôte, J., Fruhauf, C.H., 1990. La métallurgie au bois et les espaces forestiers dans les Pyrénées de l'Aude et de l'Ariège. In: Woronoff, D. (Ed.), Forges et forêts. Recherches sur la consommation proto-industrielle de bois. EHESS, Paris, pp. 151-212.

Bonhôte, J., Davasse, B., Dubois, C., Izard, V., Métailié, J.-P., 2002. Charcoal kilns and environment history in the eastern Pyrenees (France). In: A Methodological Approach, Second International Meeting of Anthracology, Paris. British Archaeological Reports International Series 1063, pp. 219-228.

Bronk Ramsey, C., 2009. Bayesian analysis of radiocarbon dates. Radiocarbon 51 (1) 337-360.

Bork, H.R., Lang, A., 2003. Quantification of past soil erosion and land use/land cover changes in Germany. In: Lang, A., Hennricht, K., Dikau, R. (Eds.), Long Term Hillslope and Fluvial System Modelling. Concepts and Case Studies from the Rhine River Catchment, pp. 231-239.

Bork, H.R., Dahlke, C., Dreibrodt, S., Kranz, A., 2009. Soil and human impact. Nova Acta Leopold 98, 63-78.

BRGM, 1979. Carte géologique de la France. Le Mas d'Azil. Map 1/50 000 and Notice. BRGM ed., Orléans.

Burjachs, F., 1994. Palynology of the upper Pleistocene and Holocene of the northeast Iberian Peninsula: Pla de l'Estany (Catalonia). Historical Biology 9, 17-33.

Burjachs, F., Julià, R., 1994. Abrupt climatic changes during the last glaciation based on pollen analysis of the Abric Romani, Catalonia, Spain. Quaternary Research 42 (3), 308-315.

Camarero, L., Masqué, P., Devos, W., Ani-Ragolta, I., Catalan, J., Moor, H.C., Pla, S., Sanchez-Cabeza, J.A. 1998. Historical variations in lead fluxes in the Pyrenees (Northeast Spain) from a dated lake sediment core. Water, Air, and Soil Pollution 105, 439-449.

Carcaillet, C., 2001. Are Holocene wood-charcoal fragments stratified in alpine and subalpine soils? Evidence from the Alps based on AMS 14C dates. The Holocene $1-2,231-242$.

Carcaillet, C., Muller, S.M., 2005. Holocene tree-limit and distribution of Abies alba in the inner French Alps: anthropogenic or climatic changes? Boreas 34, 468-476.

Carcaillet, C., Talon, B., 1996. Aspects taphonomiques de la stratigraphie et de la datation de charbons de bois dans les sols: exemple de quelques sols des Alpes. Géographie Physique et Quaternaire 50, 233-244.

Colombaroli, D., Marchetto, A., Tinner, W., 2007. Long-term interactions between Mediterranean climate, vegetation and fire regime at Lago di Massaciuccol (Tuscany, Italy). Journal of Ecology 95, 755-770.

Cunill, R., 2010. Estudi interdisciplinari de l'evolució del límit superior del bosc durant el període holocènic a la zona de Plaus de Boldís-Montarenyo, Pirineu central català. Pedoantracologia, palinologia, carbons sedimentaris i fonts documentals. PhD dissertation. Universitat Autònoma de Barcelona, Barcelona.

Cunill, R., Soriano, J.M., Bal, M.C., Pèlachs, A., Pérez-Obiol, R., 2012. Holocene treeline changes on the south slope of the Pyrenees: a pedoanthracological analysis. Vegetation History and Archaeobotany 21, 373-384.

Cunill, R., Soriano, J.M., Bal, M.C., Pèlach, s A., Rodriguez, J.M., Pérez-Obiol, R., 2013. Holocene high-altitude vegetation dynamics in the Pyrenees: a pedoanthracology contribution to an interdisciplinary approach. Quaternary International 289, 60-70.

Cunill, R., Métailié, J.-P., Galop, D., Poublanc, S., de Munnik, N., 2014. Geohistoria ambiental de los abetales (Abies alba Mill.) del piedemonte pirenaico de la región de Volvestre (Ariège, Midi Pyrenées, Francia). Un estudio interdisciplinar: fuentes documentales, pedoantracología, palinología. In: Cámara Artigas, Rafael, Rodríguez Pérez, Beatriz, Muriel Gómez, Juan Luis (Eds.), Biogeografía de Sistemas Litorales. Dinámica y Conservación. Sevilla. http:/ congreso.us.es/viiiceb/files/Libro.pdf.

Di Pasquale, G., Allevato, E., Cocchiararo, A., Moser, D., Pacciarelli, M., Saracino, A. 2014. Late Holocene persistence of Abies alba in lowmid altitude deciduous forests of central and southern Italy: new perspectives from charcoal data. Journal of Vegetation Science 25, 1299-1310.

Dreibrodt, S., Nelle, O., Lütjens, I., Mitusov, A., Clausen, I., Bork, H.R., 2009. Investigations on buried soils and colluvial layers around Bronze Age burial mounds at Bornho ved (northern Germany): an approach to test the hypothesis of "landscape openness" by the incidence of colluviation. Holocene 19, $487-497$.

Drescher-Schneider, R., De Beaulieu, J.L., Magny, M., Walter-Simonnet, A.V . Bossuet, G., Millet, L., Brugiapaglia, E., Drescher, A., 2007. Vegetation history, climate and human impact over the last 15,000 years at Lago dell'Accesa (Tuscany, Central Italy). Vegetation History and Archaeobotany 16 (4), 279-299.

Dubois, H., 1988. L'essor médiéval. In: Dupâquier, J. (Ed.), Histoire de la population française, vol. 1, pp. 207-266.

Dubois, Cl, 1996. Métallurgie du fer en Ariège de l'Antiquité au XVIIe siècle: le point sur les données archéologiques. In: Vulcain (Ed.), Actes du Symposium Paléométallurgie du fer et cultures, pp. 387-396. 
Dubois, $\mathrm{Cl}$, 2000. Elements sur l'origine de la production du fer en Ariège: le site de Lercoul. In: d'Andorra, Governa (Ed.), Gè curs d'arqueologia d'Andorra 2000 L'obtencio del ferro pel procediment directe entre els segles IV i XIX, pp. 176-188.

Dubois, C., Guilbaut, J.E., 1982. Antiques mines de cuivre du Séronais (Pyrénées Ariégeoises). In: CNRS (Ed.) Mines et fonderies antiques de la Gaule. Universite de Toulouse - Le Mirail, 21-22 novembre 1980, pp. 95-123. Table ronde du CNRS.

Dubois, C., Métailié, J.P., 2001. Anthropisation et dynamique forestière dans les Pyrénées ariégeoises à l'époque gallo-romaine. L'exemple de la forêt de Lercoul. In: Les ressources naturelles des Pyrénées. Leur exploitation dans l'Antiquité. Entretiens d'archéologie et d'histoire. St Bertrand-de-Comminges, pp. 7-19.

Ejarque, A., Julià, R., Riera, S., Palet, J.M., Orengo, H.A., Miras, Y., Gascón, C., 2009 Tracing the history of highland human management in the eastern PrePyrenees: an interdisciplinary palaeoenvironmental study at the Pradell fen, Spain. The Holocene 19 (8), 1241-1255.

Ejarque, A., Miras, Y., Riera, S., Palet, J.M., Orengo, H., 2010. Testing micro-regiona variability in the Holocene shaping of high mountain cultural landscapes: palaeoenvironmental case-study in the eastern Pyrenees. Journal of Archaeological Science 37-7, 1468-1479.

Esteban, J., Oliver, J., Còts, P., Pèlachs, A., Mendizàbal, E., Soriano, J.M., Nasarre, E. Matamala, N., 2003. La humanización de las altas cuencas de la Garona y las Nogueras (4500 aC-1955 dC). Servicio Nacional de Parques Nacionales, Madrid.

Fady, B., Forest, I., Hochu, I., Ribiollet, A., De Beaulieu, J.L., Pastuszka, P., 1999. Genetic differentiation in Abies alba Mill. populations from south-eastern France. Forest genetics 6 (3), 129-138.

Faegri, K., Iversen, J., 1989. Textbook of Pollen Analysis, fourth ed. Chichester.

Fruhauf, C., 1980. Forêt et Société. CNRS, Toulouse.

Galop, D., 1998. La forêt, l'homme et le troupeau dans les Pyrénées: 6000 ans d'histoire de l'environnement entre Garonne et Méditerranée: contribution palynologique. Geode, Toulouse.

Galop, D., 2005. Les transformations de l'environnement pyrénéen durant l'Antiquité : l'état de la question a la lumière des données polliniques. Aquitania 317-327.

Galop, D., Jalut, G., 1994. Differential human impact and vegetation history in two adjacent Pyrenean valleys in the Ariège basin, southern France, from $3000 \mathrm{BP}$ to the present. Vegetation History and Archaeobotany 3 (4), 225-244.

Galop, D., Vanniere, B., Fontugne, M., 2000. Human activities and fire history since $4500 \mathrm{BC}$ on the northern slope of the Pyrenees: a record from Cuguron (Centra Pyrenees, France). In: Thièbault, S. (Ed.), Charcoal Analysis: Methodologica Approaches, Palaeological Results and Wood Uses. Proceedings of the Second International Meeting of Anthracology, Paris, British Archaeological Reports International Series, 1063, pp. 43-51.

Galop, D., Rius, D., Cugny, C., Mazier, F., 2013. A history of long-term Human-Environment interactions in the French Pyrenees Inferred from the Pollen data. In: Lozny, L.R. (Ed.), Continuity and Change in Cultural Adaptation to Mountain Environments. Springer, New York, pp. 19-30.

Gonin, P., 1993. Les stations à intérêt forestier sur les coteaux et vallées de MidiPyrénées situées à l'est de la Garonne. Centre d'Etudes Techniques et Economiques Forestières Garonnais, Toulouse.

Gonin, P., Fady, B., Musch, B., Métailié, J.-P., Galop, D., Cunill, R., Poublanc, S., Corriol, G., Sajdak, G., Delarue, A., Vallette, P., Drenou, Ch, 2012. Caractérisation génétique et origine du Sapin pectiné (Abies alba Mill.) de Ste Croix Volvestre (Ariège) et du massif pyrénéen. In: PNR Pyrénées Ariégeoises, vol. 107. IDF. http://www.parc-pyrenees-ariegeoises.fr/.

Goron, L., 1942. Les Pyrénées ariégeoises et garonnaises. Privat éd., Toulouse.

Hubschman, J., 1975. Morphogenèse et pédogenèse dans le piémont des Pyrénées garonnaises et ariégeoises. Champion, Paris.

Jalut, G., 1974. Evolution de la végétation et variations climatiques durant les quinze derniers millénaires dans l'extrémité orientale des Pyrénées. PhD, Toulouse II.

Jalut, G., Delibrias, G., Dagnac, J., Mardones, M., Bouhours, M., 1982. A palaeoecological approach to the last 21,000 years in the Pyrenees: the peat bog of Freychinede (Alt. 1350 m., Ariege, South France). Palaeogeography, Palaeoclimatology, Palaeoecology 40, 321-359.

Jalut, G., Galop, D., Belet, J.M., Aubert, S., Amat, A.E., Bouchette, A., Dedoubat, I., Fontugne, M., 1988. Histoire des forêts du versant nord des Pyrénées au cours des 30,000 dernières années. Journal de la Société Botanique Française 5, 73-84.

Jalut, G., Aubert, S., Galop, D., Fontugne, M., Belet, J.M., 1996. Type Regions F-zg and Fr, the Northen Slope of the Pyrenees. Palaeoecological Events during the Last 15,000 Years-Regional Synthesis of Palaeoecological Studies of Lakes and Mires in Europe, pp. 612-632.

Keller, F., Lischke, H., Mathis, T., Möhl, A., Wick, L., Ammann, B., Kienast, F. 2002. Effects of climate, fire, and humans on forest dynamics: forest simulations compared to the palaeological record. Ecological Modelling 152, 109-127.

Kenla, J.V., Jalut, G., 1979. Déterminisme anthropique du développement du hêtre dans la sapinière du Couserans (Pyrénées ariègeoises, France) durant le subatlantique. Geobios 12 (5), 735-738.

Konnert, M., Bergmann, F., 1995. The geographical distribution of genetic variation of silver fir (Abies alba, Pinaceae) in relation to its migration history. Plan Systematics and Evolution 196 (1-2), 19-30.

Kozáková, R., Šamonil, P., Kuneš, P., Novák, J., Kočár, P., Kočárová, R., 2011. Contrasting local and regional Holocene histories of Abies alba in the Czech
Republic in relation to human impact: evidence from forestry, pollen and anthracological data. The Holocene 21 (3), 431-444.

Küster, H., 1994. The economic use of Abies wood as timber in central Europe during Roman times. Vegetation History and Archaeobotany 3 (1), 25-32.

Liepelt, S., Cheddadi, R., de Beaulieu, J.L., Fady, B., Gömöry, D., Hussendörfer, E., Konnert, M., Litt, T. Longauer, R., Terhürne-Berson, R., Ziegenhagen, B., 2009. Postglacial range expansion and its genetic imprints in Abies alba (Mill.) - A synthesis from palaeobotanic and genetic data. Review of Palaeobotany and Palynology 153, 139-149.

Mardones, M., Jalut, G., 1983. tourbiere de Biscaye (alt. 409 m, Hautes Pyrenees): approche paleoecologique des 45.000 dernieres annees. Pollen et spores 25, $163-212$.

Métailié, J.-P., 2006. Mountain landscape, pastoral management and traditional practices in the northern pyrenees (France). In: Agnoletti, M. (Ed.), The Conservation of Cultural Landscapes. CABI Books, pp. 108-123.

Métailié, J.P., Bonhote, J., Fruhauf, C., 1989. A thousand years of forest history in the French Pyrenees mountains: the Ariege example. In: Human Influence on Forest Ecosystems Development in Europe, Trente, 1988, 09, 26-29. Pitagora Editrice, Italia, Bologna, pp. 159-167.

Muller, S.D., Nakagawa, T., De Beaulieu, J.L., Court-Picon, M., Carcaillet, C., Miramont, C., Roiron, P., Boutterin, C., Ali, A.A., Bruneton, H., 2007. Post-glacial migration of silver fir (Abies alba Mill.) in the south-western Alps. Journal of biogeography 34 (5), 876-899.

Nakagawa, T., de Beaulieu, J.L., Kitagawa, H., 2000. Pollen-derived history of timber exploitation from the Roman period onwards in the Romanche valley, central French Alps. Vegetation history and archaeobotany 9 (2), 85-89.

Ortu, E., David, F., Caramiello, R., 2003. Role of man in the history of vegetation of the Ellero valley (maritime Alps, Italy). Comptes Rendus Biologies 326 (7), 631-637.

Pèlachs, A., 2005. Deu mil anys de geohistòria ambiental al Pirineu Central Català. Aplicació de tècniques paleogeogràfiques per a l'estudi del territori i el paisatge a la Coma de Burg i a la Vallferrera. Phd dissertation. Universitat Autònoma de Barcelona.

Pèlachs, A., Pérez-Obiol, R., Ninyerola, M., Nadal, J., 2009. Landscape dynamics of Abies and Fagus in the southern Pyrenees during the last 2200 years as a result of anthropogenic impacts. Review of palaeobotany and palynology 156 (3), $337-349$.

Pèlachs, A., Pérez-Obiols, R., Soriano, J.M., Bal, M.C., 2010. El paisatge vegetal de les Planes de Son i la Mata de València: una aproximació als darrers mil·lenis de geohistòria ambiental. Els sistemes naturals de les Planes de Son i la mata de València, vol. 16. Treballs de la Institució Catalana d'Història Natural, pp. 255-325.

Pèrez-Obiol, R., Julià, R., 1994. Climatic change on the Iberian Peninsula recorded in a 30,000-yr pollen record from Lake Banyoles. Quaternary Research 41 (1), $91-98$.

Pérez-Obiols, R., 1988. Histoire Tardiglaciaire et Holocène de la végétation de la région volcanique d'Olot (NE Péninsule Ibérique). Pollen et Spores 30 (2), $189-202$.

Reille, M., 1992-98. Pollen et spores d'Europe et d'Afrique du Nord, 3 vols. Laboratoire de Botanique Historique et Palynologie, Marseille.

Reille, M., Andrieu, V., 1995. Late-Pleistocene and Holocene in the Lourdes Basin (western Pyrenees, France): new pollenanalytical and chronological data. Vegetation History and Archaeobotany 4,1-21.

Reille, M., Loewe, J., 1993. A re-evaluation of the vegetation History of the eastern Pyrénées (France), from the end of the last Glacial to present. Quaternary Science Reviews 12, 47-77.

Reimer, P.J., Bard, E., Bayliss, A., Beck, J.W., Blackwell, P.G., Bronk Ramsey, C., Buck, C.E., Edwards, R.L., Friedrich, M., Grootes, P.M., Guilderson, T.P., Haflidason, H., Hajdas, I., Hatté, C., Heaton, T.J., Hoffmann, D.L., Hogg, A.G., Hughen, K.A., Kaiser, K.F., Kromer, B., Manning, S.W., Niu, M., Reimer, R.W., Richards, D.A., Scott, E.M., Southon, J.R., Turney, C.S.M., van der Plicht, J., 2013. IntCal13 and Marine13 radiocarbon age calibration curves, $0-50,000$ years cal BP. Radiocarbon 55, 1869-1887.

Rendu, C., Calastrenc, C., Le Couédic, M., Galop, D., Rius, D., Cugny, C., Bal, M.C. 2013. Montagnes et campagnes d'Oloron dans la longue durée. Premiers résultats d'un programme interdisciplinaire. Aquitania 29, 37-64.

Rius, D., Vannière, B., Galop, D., 2009. Fire frequency and agro-pastoral activities landscape management in the north-western Pyrenean piedmont (France) since early Neolithic (8000 cal. BP). The Holocene 19 (6), 1-13.

Rius, D., Vannière, B., Galop, D., Richard, H., 2011. Holocene fire regime changes from multiple-site sedimentary charcoal analyses in the Lourdes basin (Pyrenees, France). Quaternary Science Reviews 30, 1696-1709.

Rius, D., Vannière, B., Galop, D., 2012. Holocene history of fire, vegetation and land use from the central Pyrenees (France). Quaternary Research 77 (1), 54-64.

Robin, V., Rickert, B.H., Nadeau, M.J., Nelle, O., 2011. Assessing Holocene vegetation and fire history by a multiproxy approach: The case of Stodthagen Forest (northern Germany). The Holocene 22 (3), 337-346.

Savoie, J.-M., 1995. Les types de stations forestières des Pyrénées centrales. Front pyrénéen et haute chaîne, vallée d'Aure, haut Comminges et Couserans. ONF Midi-Pyrénées, Toulouse.

Schweingruber, F.H., 1982. Mikroskopische Holzanatomie: formenspektren mitteleuropäischer Stamm- und Zweighölzer zur Bestimmung von rezentem und subfossilem Material = anatomie microscopique du bois = microscopic wood anatomy. Birmensdorf. 
Schweingruber, F.H., 1990. Anatomy of European Wood: an Atlas for the Identification of European Trees, Shrubs and Dwarf Shrubs. Swiss Federal Institute of Forest, Snow and Landscape Research, Berne.

Serra-Diaz, J.M., Ninyerola, M., Lloret, F., 2012. Coexistence of Abies alba (Mill.) Fagus sylvatica (L.) and climate change impact in the Iberian Peninsula: a climaticniche perspective approach. Flora-Morphology, Distribution, Functional Ecology of Plants 207, 10-18.

Taillefer, F., 1951. Le Piémont des Pyrénées Françaises. Contribution a l'étude des reliefs de piémont. Phd dissertation. Université de Toulouse, France.

Talon, B., Carcaillet, C., Thinon, M., 1998. Études pédoanthracologiques des variations de la limite supérieure des arbres au cours de l'Holocène dans les Alpes françaises. Géographie physique et Quaternaire 52 (2), 195-208.

Terhürne-Berson, R., Litt, T., Cheddadi, R., 2004. The spread of Abies throughout Europe since the last glacial period: combined macrofossil and pollen data. Vegetation history and Archaeobotany 13 (4), 257-268.

Tinner, W. Lotter, A.F., 2006. Holocene expansions of Fagus silvatica and Abies alba in central Europe: where are we after eight decades of debate. Quaternary Science Reviews 25, 526-549.
Tinner, W., Hubschmid, P., Wehrli, M., Ammann, B., Conedera, M., 1999. Long-term forest fire ecology and dynamics in southern Switzerland. Journal of Ecology 87, 273-289.

Tinner, W., Colombaroli, D., Heiri, O., Henne, P., Steinacher, M., Untenecker, J., Vescovi, E., Allen, R.M., Carraro, J., Conedera, G., Joos, M., Lotter, A.F. Luterbacher, J., Samartin, S., Valsecchi, V., 2013. The past ecology of Abies alba provides new perspectives on future responses of silver fir forests to global warming. Ecological Monographs 83 (4), 419-439.

Van der Knaap, W.O., van Leeuwen, J.F. Ammann, B., 2004. The first rise and fall of Fagus sylvatica and interactions with Abies alba at Faulenseemoos (Weiss Plateau) 6900-6000 cal yr BP. Acta Palaeobotanica 44 (2), 249-266.

Vernet, J.-L., Ogereau, P., Figueiral, I., Machado Yanes, C., Uzquiano, P., 2001. Guide d'identification des charbons de bois préhistoriques et récents, Sud-Ouest de l'Europe: France, Péninsule ibérique et Îles Canaries. CNRS, Paris.

Wick, L., Möhl, A., 2006. The mid-Holocene extinction of silver fir (Abies alba) in the Southern Alps: a consequence of forest fires? Palaeobotanical records and forest simulations. Vegetation History and Archaeobotany 15 (4), 435-444. 